\title{
ASSESSMENT OF GENETIC VARIABILITY AND HERITABILITY IN SEGREGATING POPUATIONS
}

\section{PRABHU. S. $M^{1}$, N. MEENAKSHI GANESHAN ${ }^{2}$, P. JAYAPRAKASH ${ }^{3} \&$ R. SELVAKUMAR ${ }^{4}$}

${ }^{1,4}$ Rasi seeds (P) Ltd., Attur, Salem, Tamil Nadu, India

${ }^{2,3}$ Tamilnadu Agricultural University, Coimbatore, Tamil Nadu, India

\begin{abstract}
The present study was carried out to assess the genetic variability, heritability, genetic advance for yield and yield component characters in two cross viz., BPT 5204 X ADT 45 and BPT 5204 X JGL 1798. In general, most of the characters viz., plant height, number of productive tillers, filled grains per panicle, spikelet fertility, 1000 grain weight, seed yield per plant, grain length, grain width and L/B ratios in cross BPT $5204 X$ ADT 45 having higher mean performance when compared with the cross BPT 5204 X JGL 1798. High PCV and GCV showed high heritable variation which was recorded high in the characters viz., productive tillers per plant, and sterile grains per panicle and grain yield per panicle in both the crosses. Selection may be effective for the character with high heritability accompanied with high genetic advance which indicated that the heritability is due to additive gene effects. Similarly, high heritability with high genetic advance was observed for grain width in cross BPT 5204 X ADT 45 and the characters grain breadth and L/B ratios in cross BPT 5204 X JGL 1798.
\end{abstract}

KEYWORDS: Rice, Variability, PCV, GCV, Heritability \& Genetic Advance

Received: Apr 03, 2017; Accepted: May 06, 2017; Published: May 26, 2017; Paper Id.: IJASRJUN201734

\section{INTRODUCTION}

Rice is the most important crop among the cereals grown in India and the world. Rice is considered as the "Global grain" because of more than half of the global population used as staple food. Asia is considered to be "rice bowl" of the world, and it produces and consumes more than 90 per cent of world rice. A quantum jump in yield improvement has been achieved in rice with the development of high yielding heterotic hybrids under commercial cultivation. So, it is critical to produce high yielding cultivars with high quality by inbreeding methods. The study of genetic variability is the pre-requisite for any crop improvement program. Genetic variability studies provide basic information regarding the genetic parameters of the population based on which breeding methods are formulated for further improvement of the crop. Heritability estimates of quantitative characters play an important role in expressing the reliability of variance value as a selection guideline to the plant breeder. Heritability along with genetic advancement should be jointly considered to arrive at a more reliable conclusion (Johnson et al., 1955). Selection on the basis of grain yield character alone is usually not very effective and efficient. However, selection based on its components and secondary characters could be more efficient and reliable. The genetic variation such as PCV, GCV, heritability and genetic advances would benefit breeders in designing the most appropriate breeding approaches for developing a rice variety. The present study was formulated to study the genetic variability of yield and its contributing characters in segregating populations (F2) of two different crosses. 


\section{MATERIALS AND METHODS}

The present experiment was carried out at Rasi Seeds (P) Ltd., Attur, Salem, located at $22^{0} 57^{\prime} \mathrm{N}$ latitude and $72^{\circ} 54^{\prime} \mathrm{E}$ longitudes at an altitude of $119.8 \mathrm{~m}$ above the mean sea level. The soil of the experimental site is heavily black and fine textured with $\mathrm{pH}$ ranges from 7. 5 to 8.0. It receives an average annual rainfall of $760 \mathrm{~mm}$. The materials comprised of three parental lines viz., BPT 5204, ADT45, JGL 1798 obtained from Germplasm divisions of Rasi Seeds (P) Ltd. By using these three lines, two different crosses BPT 5204 X ADT 45 and BPT 5204 X JGL 1798 were made during kharif'13. The $\mathrm{F}_{1}$ seeds from the above two crosses were raised during rabi'13. Parental lines and $\mathrm{F}_{1}$ 's were saved during the same season to obtain seeds of parental lines and $F_{2}$ 's. The $F_{2}$ plants from each cross along with three parents as a check were raised during kharif' 14 by adopting a spacing of 15 X $10 \mathrm{~cm}$ with single seedling per hills in nonreplicated plots. All the recommended package of practices formulated by TNAU was followed along with necessary prophylactic plant protection measures to raise a good crop. Exhibited mean performance for biomedical traits in F2 generations for almost all the economic characters, including yield among the two crosses BPT 5204 X ADT 45 and BPT 5204 X JGL 1798 were observed. Data were recorded for 200 plants in the F2's respectively, for days to 50 percent flowering (days), plant height $(\mathrm{cm})$, number of productive tillers per plant, panicle length $(\mathrm{cm})$, number of filling grains per panicle, number of grains per panicle, spikelet fertility, grain length (mm), grain breadth (mm), grain width (mm), L/B ratio, amylase content, Alkaline spreading value, 1000 grain weight (g) and Grain yield per plant in single plant observation. These data were subjected to statistical analysis. Standard statistical procedure was used for the analysis of genotypes and phenotypes coefficients of variation (Burton, 1952), heritability (Lush, 1940) and genetic advance.

\section{RESULTS AND DISCUSSIONS}

The importance of variability in early segregations was given by Sivasubramanian and Mathavemenon (1973). The performance of the cross is estimated not only by using mean performance, but also on the extent of variability. Successful crop breeding lies in knowledge on the nature and magnitude of genotypic and phenotypic variation (Allard, 1960). In the present study, considerable variations were observed in the mean performance of the $F_{2}$ populations over two crosses viz., BPT 5204 X ADT 45 and BPT 5204 X JGL 1798 for 15 different characters. The range of variation was higher in cross A compared with cross B which depicted in figure 1.

High mean values always remain as main and the simplest selection index in the choice of genotypes (Pachel, 2014). Between two crosses, the high mean value of seed yield per plant in the cross BPT 5204 X ADT 45 was $25.67 \mathrm{~cm}$ with the range of 7.0 GM and 46.0 GM. Similarly, high mean performance was seen in the cross BPT 5204 X ADT 45 for the character 1000 grain weight $(15.22 \mathrm{GM})$, plant height $(101.75 \mathrm{~cm})$, number of productive tillers per plant (15.82), filled grains per panicle (219.38), spikelet fertility $(81.61 \%)$, grain length $(7.46 \mathrm{~mm})$, grain width $(1.75 \mathrm{~mm})$ and a $\mathrm{L} / \mathrm{B}$ ratio (3.41) than the BPT 5204 X JGL 1798. The mean performance of the characters viz., panicle length $(21.86 \mathrm{~cm})$, number of grains per panicle (273.03), grain breads (2.25 mm), amylase content (23.29\%) and alkaline spreading values (3.58) were recorded more in the BPT 5204 X JGL 1798. In general, BPT 5204 X ADT 45 had a high mean performance for most of the characters and had low sterile grains per panicle (51.54) and was early (Days to 50\% flowering - 93.92 days) than the BPT 5204 X JGL 1798.

In the present study, the phenotypes variances were greater than the genotypic variance for all the characters studied in $\mathrm{F}_{2}$ populations of both the crosses. This indicated that the environment has a greater influence on all the characters studied. The phenotypic coefficient of variation (PCV) was higher than the genotype coefficient of variation 
(GCV) in both the populations which also indicated that higher environmental influence on the expression of all the characters. High PCV and GCV were observed for productive tillers per plant, sterile grains per panicle, grain yield per panicle in both the population and filled grains per panicle in $\mathrm{F}_{2}$ populations of cross $\mathrm{A}$. This showed that the variations observed in these characters contributed markedly to the total variability. High PCV and moderate GCV were observed for the number of grains per panicle in cross A. Selection will be effective based on the heritable nature of that character. Panicle length in cross A and the grain breads in cross B had moderate PCV and low GCV. Moderate PCV and GCV were recorded in plant height, spikelet fertility, alkaline spreading value in both the crosses and the characters such as amylase content in cross A and also the characters, filled grains per panicle, number of grains per panicle, L/B ratios in cross B. The characters viz., 50\% flowering, 1000 grain weight, grain length and grain width in both the cross A and B and grain breads and L/B ratio in cross A and also the characters panicle length and amylose content in cross B recorded low PCV and GCV. This indicated that the variability of these characters among these populations was meager.

The present investigation revealed that all the 15 characters showed high heritability in segregating populations of both the crosses, except grain breadth, which had moderate heritability in cross A. Heritability in conjugation with genetic advance is more effective and reliable in predicting the resultant effect of selection and based on which, selection procedure can be evaluated. According to Panse (1967), such characters were found to be governed by additive gene action. The results indicated the presence of additive gene effects and consequently a high genetic gain could be expected from phenotypic selection. High heritability with high genetic advance was observed for grain width in cross A and the characters grain breadth and L/B ratios in cross B. High heritability accompanied with high genetic advance indicated that most likely the heritability is due to additive gene effects and the selection may be effective for these characters.

\section{CONCLUSIONS}

Highly heritable with moderate genetic advance was observed in productive tillers per plant, alkaline spreading value and grain yield per plant in segregating populations of both crosses A and B and the characters such as sterile grains per panicle, grain breads and amylose content in Cross A and also the character grain width in cross B also having similar effect. High heritability with low genetic advance was observed in days to $50 \%$ flowering, plant height, panicle length, filled grains per panicle, number of grains per panicle, spikelet fertility, grain length, amylose content and grain yield per plant in both the crosses and sterile grains in cross B. High heritability with low genetic advance was observed for days to maturity in summer season. It is an indication for non-additive gene action for the above mentioned characters. High heritability was due to conducive environment, rather than genotypic and selection of such characters may not be rewarding.

\section{REFERENCES}

1. Allard, R.W., 1960. Principle of Plant Breeding. John Wiley and Sons Inc., New York, USA.

2. Jennings P. R, Coffman, W and Kauffman, H. E, (1979). Rice Improvement, International Rice Research Institute, Los Banos, Laguna.

3. Johnson, HW, Robinson, HF Comstock, RE Estimation of genetic and environmental variability in soybeans. Agronomy J. 1955 47: 314-318.

4. Nancy A. Eckardt. 2000. Sequencing the rice genome. The Plant Cell. pp: $2011-2017$.

5. Panse, V.G. and Sukhatme, P.V., 1967, Statistical Methods for Agricultural Workers. Indian Council of Agricultural Research, 
New Delhi.

6. Pingali, P. L. 1990, "Institutional and Environmental Constraints to Agricultural Intensification", in Geoffrey McNicoli and Mead Cain (eds) Rural Development and Population, Oxford University Press and the Population Council Inc., New York, pp.243-260.

7. Sivasubramanian, S. and P. M. Menon. 1973. Genotypic and phenotypic variability in rice. Madras Agric. J., 60 (9-13): 10931096.

8. Sumathi P, Sumamth M, Vearabadhiran P. 2010. Genetic Variability for Different Biometrical Traits in Pearl Millet Genotypes (Pennisetum glaucum L.R. Br.). Electronic Journal of Plant Breeding, 1 (4): 347-440.

\section{APPENDICES}

Table 1: Mean Performance and Range in F2 Population of Crosses BPT 5204 X ADT 45 and BPT 5204 X JGL 1798

\begin{tabular}{|c|c|c|c|c|c|c|c|c|c|}
\hline S. No. & Characters & Cross Details & Min & Max & Mean & PCV & GCV & $\mathbf{h}^{2}$ & GAM \\
\hline \multirow{2}{*}{1} & \multirow{2}{*}{$\begin{array}{l}\text { Days to } 50 \% \\
\text { flowering }\end{array}$} & BPT 5204 X ADT 45 & 80.00 & 109.00 & 93.92 & 7.22 & 7.16 & 98.40 & 2.01 \\
\hline & & BPT 5204 X JGL 1798 & 77.00 & 110.00 & 94.24 & 7.68 & 7.64 & 99.00 & 1.86 \\
\hline \multirow{2}{*}{2} & \multirow{2}{*}{ Plant height $(\mathrm{cm})$} & BPT 5204 X ADT 45 & 71.50 & 137.00 & 101.75 & 11.00 & 10.69 & 94.36 & 3.12 \\
\hline & & BPT 5204 X JGL 1798 & 65.90 & 121.00 & 94.67 & 11.63 & 11.15 & 92.00 & 3.53 \\
\hline \multirow[b]{2}{*}{3} & \multirow{2}{*}{$\begin{array}{l}\text { Number of } \\
\text { productive tillers } \\
\text { /plant }\end{array}$} & BPT 5204 X ADT 45 & 9.00 & 31.00 & 15.82 & 23.06 & 20.39 & 78.20 & 13.29 \\
\hline & & BPT 5204 X JGL 1798 & 8.00 & 26.00 & 14.83 & 23.77 & 20.07 & 71.27 & 13.61 \\
\hline \multirow{2}{*}{4} & \multirow{2}{*}{ Panicle length $(\mathrm{cm})$} & BPT 5204 X ADT 45 & 16.90 & 29.00 & 21.86 & 11.14 & 9.73 & 76.39 & 7.83 \\
\hline & & BPT 5204 X JGL 1798 & 17.50 & 26.50 & 22.20 & 8.95 & 8.30 & 86.03 & 6.88 \\
\hline \multirow{2}{*}{5} & \multirow{2}{*}{\begin{tabular}{|l} 
Filled \\
grains/Panicle
\end{tabular}} & BPT 5204 X ADT 45 & 84.00 & 342.00 & 219.38 & 22.95 & 20.96 & 83.40 & 3.55 \\
\hline & & BPT 5204 X JGL 1798 & 154.00 & 312.00 & 217.23 & 16.65 & 13.80 & 68.73 & 2.93 \\
\hline \multirow{2}{*}{6} & \multirow{2}{*}{$\begin{array}{l}\text { Sterile } \\
\text { grains/Panicle }\end{array}$} & BPT 5204 X ADT 45 & 10.00 & 197.00 & 51.45 & 73.23 & 60.67 & 68.64 & 12.62 \\
\hline & & BPT 5204 X JGL 1798 & 13.00 & 165.00 & 55.80 & 58.48 & 57.50 & 96.66 & 8.71 \\
\hline \multirow{2}{*}{7} & \multirow{2}{*}{$\begin{array}{l}\text { Number of grains } \\
\text { /panicle }\end{array}$} & BPT 5204 X ADT 45 & 133.00 & 459.00 & 270.83 & 23.16 & 19.14 & 68.32 & 3.09 \\
\hline & & BPT 5204 X JGL 1798 & 177.00 & 437.00 & 273.03 & 18.11 & 15.78 & 75.84 & 2.82 \\
\hline \multirow{2}{*}{8} & \multirow{2}{*}{$\begin{array}{l}\text { Spikelet fertility } \\
(\%)\end{array}$} & BPT 5204 X ADT 45 & 53.11 & 95.94 & 81.61 & 12.73 & 10.02 & 61.87 & 3.96 \\
\hline & & BPT 5204 X JGL 1798 & 52.98 & 93.43 & 80.27 & 10.84 & 10.56 & 94.89 & 3.42 \\
\hline \multirow{2}{*}{9} & \multirow{2}{*}{$\begin{array}{l}1000 \text { grain weight } \\
\text { (g) }\end{array}$} & BPT 5204 X ADT 45 & 12.50 & 18.20 & 15.22 & 6.99 & 6.97 & 99.52 & 3.66 \\
\hline & & BPT 5204 X JGL 1798 & 12.40 & 18.60 & 15.12 & 6.21 & 6.19 & 99.50 & 3.5 \\
\hline \multirow{2}{*}{10} & \multirow{2}{*}{$\begin{array}{l}\text { Seed yield /plant } \\
(\mathrm{gm})\end{array}$} & BPT 5204 X ADT 45 & 7.00 & 46.00 & 25.67 & 35.73 & 29.53 & 68.31 & 12.46 \\
\hline & & BPT 5204 X JGL 1798 & 7.00 & 46.00 & 24.73 & 33.61 & 32.46 & 93.27 & 11.41 \\
\hline \multirow{2}{*}{11} & \multirow{2}{*}{ Grain Length (mm } & BPT 5204 X ADT 45 & 6.25 & 8.25 & 7.46 & 4.98 & 4.26 & 72.92 & 8.86 \\
\hline & & BPT 5204 X JGL 1798 & 6.30 & 8.34 & 7.30 & 6.21 & 5.85 & 88.76 & 9.77 \\
\hline \multirow{2}{*}{12} & \multirow{2}{*}{$\begin{array}{l}\text { Grain Breadth } \\
(\mathrm{mm})\end{array}$} & BPT 5204 X ADT 45 & 1.83 & 2.75 & 2.21 & 8.27 & 6.04 & 53.37 & 17.58 \\
\hline & & BPT 5204 X JGL 1798 & 1.45 & 2.87 & 2.25 & 11.72 & 9.52 & 66.08 & 23.72 \\
\hline \multirow{2}{*}{13} & \multirow{2}{*}{ Grain Width (mm) } & BPT 5204 X ADT 45 & 1.45 & 1.98 & 1.75 & 5.82 & 5.20 & 79.86 & 20.09 \\
\hline & & BPT 5204 X JGL 1798 & 1.40 & 1.98 & 1.72 & 6.05 & 5.03 & 68.97 & 19.9 \\
\hline \multirow{2}{*}{14} & \multirow{2}{*}{ L/B Ratio } & BPT 5204 X ADT 45 & 2.77 & 4.04 & 3.41 & 8.22 & 7.14 & 75.49 & 16.99 \\
\hline & & BPT 5204 X JGL 1798 & 2.38 & 5.38 & 3.29 & 12.03 & 10.07 & 70.15 & 20.44 \\
\hline 15 & Amylose content & BPT 5204 X ADT 45 & 17.50 & 26.50 & 22.80 & 10.21 & 10.13 & 98.37 & 4.85 \\
\hline $1 J$ & $(\%)$ & BPT 5204 X JGL 1798 & 18.00 & 26.80 & 23.29 & 8.58 & 8.31 & 93.69 & 5.87 \\
\hline 16 & Alkaline Spreadin & BPT 5204 X ADT 45 & 3.00 & 4.30 & 3.58 & 10.80 & 10.29 & 90.76 & 17.91 \\
\hline 10 & Values & BPT 5204 X JGL 1798 & 3.00 & 4.30 & 3.67 & 10.43 & 10.03 & 92.42 & 16.84 \\
\hline
\end{tabular}

